\title{
CONTROL METHODS OF VESSEL'S THRUSTER AT CHANGING OPERATING CONDITIONS
}

\author{
Nahovskyi D. A., Ph.D., Associate Professor Department of Operation vessel electrical \\ equipment and Automation, Kherson State Maritime Academy, e-mail: \\ dymon.ksu@gmail.com,ORCID: 0000-0001-6920-0324
}

Doschenko G. G., Ph.D., Associate Professor, Department of Operation vessel electrical equipment and Automation, Kherson State Maritime Academy, e-mail: hersongala@gmail.com

\begin{abstract}
It has been substantiated that in order to improve the operational characteristics of the vessel thrusters, it is necessary to use the torque and power control. It has been shown that torque and power control are feasible solutions for high-performance thruster control only if special precautions are taken during extreme environmental conditions, when the propeller may be subject to ventilation and in-and-out-of water effects. Therefore, an anti-spin thruster controller has been designed.

The results have showed that the torque and power controllers with anti-spin have comparable performance to that of a well-tuned shaft speed PI controller during ventilation, without compromising the superior performance of torque and power control in normal conditions.

Keywords: anti-spin controller, control, thruster, torque, model, power, ventilation effect.
\end{abstract}

\section{DOI: 10.33815/2313-4763.2019.1.20.097-108}

Introduction. The power plant on ships consists of several gas turbines or diesel engines driving electrical generators. In order to ensure the safe operation, there must, in all load conditions, be enough spinning reserves providing sufficient available power for unpredictable variations in load in order to prevent a blackout.

The blackout prevention, by means of reducing the load on heavy consumers, must typically respond faster than $500 \mathrm{~ms}$ to be effective. With torque and power control, the propeller load is less sensitive to ambient variations, which produces less power disturbances and improves voltage and frequency quality. Additionally, the maximum power consumption may easily be limited to available power in both schemes, since the power limitation is explicit in the torque and power control algorithm. This, in contrast to controlled speed and pitch propellers, where the actual power load must be measured as a feedback signal with an inherent time lag, which declines the blackout prevention response time. The accurate and fast control of power and power limitation in torque and power control gives less unpredictable load changes and less available power demand. Consequently, there will be a reduced probability of blackout due to overload, since unintentional power peaks will be suppressed. In conventional speed controlled drives, the excess of controlled torque/power may occur up to $5 \%$. If this occurs for several thrusters simultaneously, significantly more power is being consumed than requested by the positioning system.

In this context, in order to reduce this dependence, it is required to find out new laws of thruster control.

Aim of work - to define thruster control methods when changing operational conditions.

Results and discussion. Ventilation, cavitation, loss of effective disc area, and the Wagner effect are all closely related physical phenomena. Let $\mathrm{Qm}$ denote the torque generated by the propeller drive. A torque balance for the propeller shaft is written [1]:

$$
I_{s} \omega=Q_{m}-Q_{a}-Q_{f}(\omega)
$$

where $I_{s}$ is the moment of shaft, propeller, and drive inertia, $\omega=2 \pi n$ is the angular shaft speed, and $Q_{f}(\omega)$ is the shaft friction, $Q_{a}-$ is the shaft torque.

In commonly, the friction may be considered as a sum of static friction (or starting torque) $Q_{s}$ and a linear component:

$$
Q_{f}(\omega)=\tanh (\omega / \varepsilon) Q_{s}+K_{\omega} \omega
$$


where $\varepsilon>0$ is an appropriately chosen small constant, and $K_{\omega}$ is a linear friction coefficient. On request, more complex friction models may be used, including e.g. nonlinear elements, Stribeck friction, and hysteresis effects.

As detailed in [1], the load torque assessment may be used for valuation multiples calculation of torque loss $\beta_{Q}$

From (1) the following control unit model of the thruster dynamics is proposed:

$$
\begin{aligned}
& I_{s} \omega=Q_{m}-Q_{a}-Q_{f f 0}\left(n_{r}\right)-Q_{f 1 \omega}+\delta_{f}, \\
& Q_{a}=\omega_{q},
\end{aligned}
$$

$Q_{a}$ is here assumed to be a bias term due to an external bounded disturbance $\omega_{q}$. It is required to capture the fast transients during ventilation. The static friction compensation term $Q_{f f o}\left(n_{r}\right)$ from [1] is used instead of a static friction model based on $\omega$ in order to avoid oscillations in this term about $\omega \approx 0$. $\delta_{f}$ allows for errors in the friction model. With the measurement $y=\omega+v$ being contaminated with a bounded disturbance $v$, and $\hat{y}=\omega$, the propeller load torque observer copying the control unit model [1] is:

$$
\begin{aligned}
& \left.\hat{\omega}=1 / I_{s} \mid Q_{m}-\hat{Q}_{a}-Q_{f f 0}\left(n_{r}\right)-Q_{f 1} \hat{\omega}\right\rfloor+k_{a}(y-\hat{y}), \\
& \hat{Q}_{a}=k_{b}(y-\hat{y}),
\end{aligned}
$$

where $k_{a}$ and $k_{b}$ are the observer gains. In [2] it is shown that with a constant load torque $Q_{a}$ implied by $\omega_{q}=0$, zero measurement disturbance $v=0$, and advanced friction knowledge such that $\delta_{f}=0$, the equilibrium point of the observer estimation error is globally exponentially stable (GES) if the observer gains are chosen as $k_{a}>-Q_{f l} / I_{s}$ and $k_{b}<0$.

For DP operation, the expected nominal propeller load torque $\hat{O}_{n}$ may be calculated by feedback from the propeller shaft speed $n$. The estimated torque loss factor $\beta_{\mathrm{Q}}$ is calculated [2] from $\hat{O}_{a}$ and $\hat{O}_{n}$ as:

$$
\hat{\beta}_{Q}=\frac{\hat{Q}_{a}}{\hat{Q}_{n}}=\frac{\hat{Q}_{a}}{K_{Q C} \rho D^{5} n|n|}, \quad n \neq 0,
$$

where the control coefficient $K_{Q C}$ is used to calculate $\hat{O}_{n}$.

Thruster normal operation suggests minimum ventilation effects. The ventilation detection algorithm is implemented by defining limits for the onset and termination of ventilation $\beta_{v, \text { on }}$ and

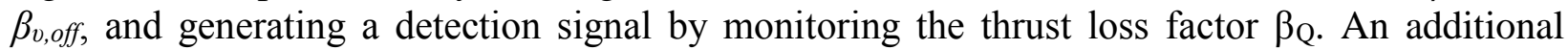
criterion for detection is that the magnitude of the thruster torque $Q_{m}$ doesn't increase. The ventilation incident will then show the following evolution of the detection signal $\zeta$, with time instants $t_{1}<t_{2}<t_{3}$ :

$$
\begin{array}{ll}
t_{1}: \quad \hat{\beta}_{Q}>\beta_{v, \text { on }} & \Rightarrow \xi=0, \\
t_{2}: \quad \hat{\beta}_{Q}<\beta_{v, o n} \cap \operatorname{sign}\left(Q_{m}\right) \dot{Q}_{m} \leq 0 & \Rightarrow \xi=1, \\
t_{3}: \quad \hat{\beta}_{Q} \geq \beta_{v, o f f} & \Rightarrow \xi=0 .
\end{array}
$$

To avoid switching and chattering of the detection signal due to measurement noise and transients, an algorithm implementing a detection delay is added, such that once ventilation has been detected, it cannot be reset until after a set time interval $T_{\text {vent }}$. The detection delay can be seen as an implementation of the switching delay time proposed in $[3,6]$. This ventilation detection scheme has shown good performance in both simulations and experiments.

The torque and power controllers, although advantageous for normal operating conditions, will show unacceptable behavior when subject to large thrust losses. The nature of this problem is in many ways similar to that of a car wheel losing traction on a slippery surface during acceleration or braking. The work on anti-spin thruster control has therefore been motivated by similar control 
strategies in car anti-spin and ABS braking systems. For normal operating conditions, the proposed anti-spin control scheme is divided into two:

1. Primary anti-spin action: override the core controller and take control of the shaft speed.

2. Secondary anti-spin action: lower the setpoint of the controller to reduce the shaft speed.

Since both the structures of the physical systems and the control objectives are similar, the development of the thruster anti-spin control system has been motivated by similar hybrid control strategies in car anti-spin and ABS systems, see, for example [4] or [5, 7] with such model as:

$$
\begin{aligned}
& I_{\omega} \dot{\omega}_{\omega}=-r F_{x}+Q_{\omega}, \\
& \frac{F_{x}}{F_{z}}=\mu(\lambda), \\
& m \dot{v}=F_{x},
\end{aligned}
$$

where $I_{\omega}$ is the wheel rotational inertia, $\omega_{\omega}$ is the wheel angular velocity, $r$ is the wheel radius, $F_{x}$ is the tire friction force, $Q_{\omega}$ is the breaking or accelerating input torque to the wheel from brakes and motor, $F_{z}$ is the vertical force between tire and road, $\mu$ is the tire friction coefficient, $\lambda$ is the wheel slip, $m$ is the mass of a car, and $v$ is the car speed.

When comparing the two models for propulsion and car anti-spin, many similarities may be noticed. The rotational dynamics of the propeller and the wheel are identical, with inertial terms $I_{s} \omega$ and $I_{\omega} \omega_{\omega}$, motor input terms $Q_{m}$ and $Q_{m}$, and load torque terms $Q_{a}=f_{Q}(\Theta, \zeta)$ and $r F_{x}=r F_{z} \mu(\lambda)$ respectively.

In both cases, the aim of the anti-spin control is to optimize the load torque through control of the motor input. For car anti-spin, too high input torque will lead to loss of friction through spin (acceleration) or wheel lock (braking), and hence reduced acceleration or stopping force. For thruster anti-spin, too high load on a propeller operating close to the free surface will lead to loss of torque through ventilation, and hence loss of thrust. In addition, the propeller load torque and tire friction force depend on many other parameters, most of which are unknown to the controller.

So, if a ventilation incident is detected by the detection algorithm in (6), the desired primary anti-spin control action is to take control of the shaft speed until the ventilation has terminated. This can be done by modifying the core controller output $Q_{c i}$ [2] with a torque scaling factor $\gamma$ :

$$
Q_{c a s}=\gamma Q_{c i},
$$

where $Q_{\text {cas }}$ is the anti-spin commanded torque, and $\gamma$ is proposed as:

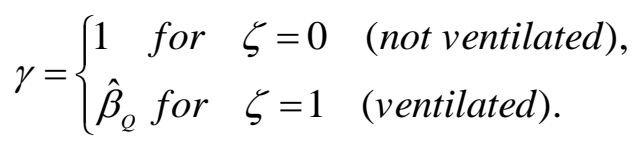

That the anti-spin control law will give a bounded shaft speed during ventilation.

To optimize the thrust and reduce the wear and tear due to dynamic propeller loading during ventilation, it may desirable to reduce the propeller shaft speed. This can be done by modifying the thrust reference during ventilation since the primary anti-spin control action assures that the shaft speed is kept close to its reference. The desired shaft speed during ventilation, $n_{a s}$, will be a thruster specific parameter, and must be chosen as a trade-off between thrust production, wear and tear, and response time. The nominal shaft speed reference $n_{r}$ should not be changed to $n_{a s}$ instantaneously, as this will lead to undesired transients. It is therefore proposed to add a lowpass filter with time constant $\tau_{n}$ and a rate limiting algorithm to the change from $n_{r}$ to $n_{a s}$ at ventilation detection, and from $n_{a s}$ to $n_{r}$ at ventilation termination. The filtered and rate limited shaft speed reference is termed $n_{\text {ras }}$, i.e. $n_{\text {fall }}<n_{\text {ras }}<n_{\text {rise }}$, where $n_{\text {fall }}$ and $n_{\text {rise }}$ are the rate limits. The thrust reference corresponding to $n_{\text {ras }}$ is termed $T_{\text {ras }}$ :

$$
T_{\text {ras }}=\operatorname{sign}\left(n_{\text {ras }}\right) K_{T C} \rho D^{4} n_{\text {ras }}^{2},
$$

where $\mathrm{K}_{\mathrm{TC}}$ is strictly positive thrust control coefficient. 
Perfect shaft speed control during ventilation would be possible if the ventilation incident could be foreseen, and $\beta(t, \omega)$ was known. However, since the propeller torque is not available as a measurement, and the ventilation incidents are random processes caused by wave elevation and vessel motion, this is not possible. An implementable solution is to use the torque loss estimation and ventilation detection schemes. The deviation of the shaft speed from the steady-state solution will then depend on the deviation of the torque modification factor $\gamma$ from the actual torque loss factor $\beta(t, \omega)$ during ventilation.

To achieve the best possible control over the shaft speed during ventilation, $\gamma$ should be switched from 1 to $\hat{\beta}_{Q}$ immediately when ventilation is detected. However, in order to avoid transients in the control input, the transition of $\gamma$ from 1 to $\hat{\beta}_{Q}$ at ventilation detection, and from $\hat{\beta}_{Q}$ to 1 at ventilation termination, should be rate limited, i.e. $\gamma_{\text {fall }}<\gamma<\gamma_{\text {rise. }}$. The rate limits $\gamma_{\text {rise }}$ and $\gamma_{\text {fall }}$ would typically be of magnitude 1 . Furthermore, to avoid using the potentially noisy estimate $\hat{\beta}_{Q}$ directly in the control law, it may be beneficial to filter $\gamma$ by a properly chosen low-pass filter with time constant $\tau_{\gamma}$.

A block diagram of the resulting thruster controller with anti-spin is shown in fig. 1.

In order to analyze the performance and the robustness of the control laws given above we will demonstrate the sensitivity subject to thrust losses. In order to compare the different control schemes a simplified sensitivity analysis is carried out to address the most significant properties of speed control, torque control and power control. Pitch control is not studied, but is expected in general to have the same behavior as speed control.



Figure1 - The anti-spin control scheme, including core controller, torque observer, loss calculation, ventilation detection, and anti-spin control actions

The experiments were conducted at basin $60 \mathrm{~m}$ long, $9.5 \mathrm{~m}$ wide, and $1.5 \mathrm{~m}$ deep, and were equipped with a towing carriage and a wave-maker system. Two types of setups were used during 
the various tests. The tested propeller was of conventional design with 4 blades, pitch ratio at 70 $\%$ of the propeller radius $P / D=1.0$, and expanded blade area ratio $E A R=0.55$.

The propeller was tested both with and without duct. For the results presented here a duct was used for the anti-spin tests only. The propeller was attached to a shaft equipped with thrust and torque sensors inside an underwater housing, and driven by an electric motor via shafts and gears with gear ratio 1:1. The rig with motor, gears, underwater housing, shaft and propeller were fixed to the towing carriage on a vertical slide, which was used to control the submergence of the propeller relative to the free surface. Ventilation incidents could hence be generated by moving the propeller vertically with a calm free surface. The motor torque was controlled from a PC onboard the carriage, using feedback from the propeller shaft speed and the motor torque. The control code was generated by rapid prototyping using Opal RT-Lab and source code in Matlab/Simulink [8].

A sketch of the experimental setup is given in fig.2. The main characteristics of the ducted propeller and drive system are summarized in table 1 . The nominal thrust and torque coefficients for the propeller without duct were found to be $K_{T O}=0.570$ and $K_{Q 0}=0.0750$. The nominal thrust and torque coefficients for reversed thrust were found to be $K_{T O r}=0.395$ and $K_{Q 0 r}=0.0665$.

Table 1 - Main propeller data

\begin{tabular}{|c|c|c|c|c|c|}
\hline $\mathrm{D}(\mathrm{m})$ & $\mathrm{K}_{\mathrm{T} 0}$ & $\mathrm{~K}_{\mathrm{Q} 0}$ & $\mathrm{I}_{\mathrm{S}}\left(\mathrm{kgm}^{2}\right)$ & $\mathrm{Q}_{\mathrm{s}}(\mathrm{Nm})$ & $\mathrm{K}_{\omega}(\mathrm{Nms})$ \\
\hline 0.25 & 0.513 & 0.0444 & 0.05 & 1.0 & 0.01 \\
\hline
\end{tabular}

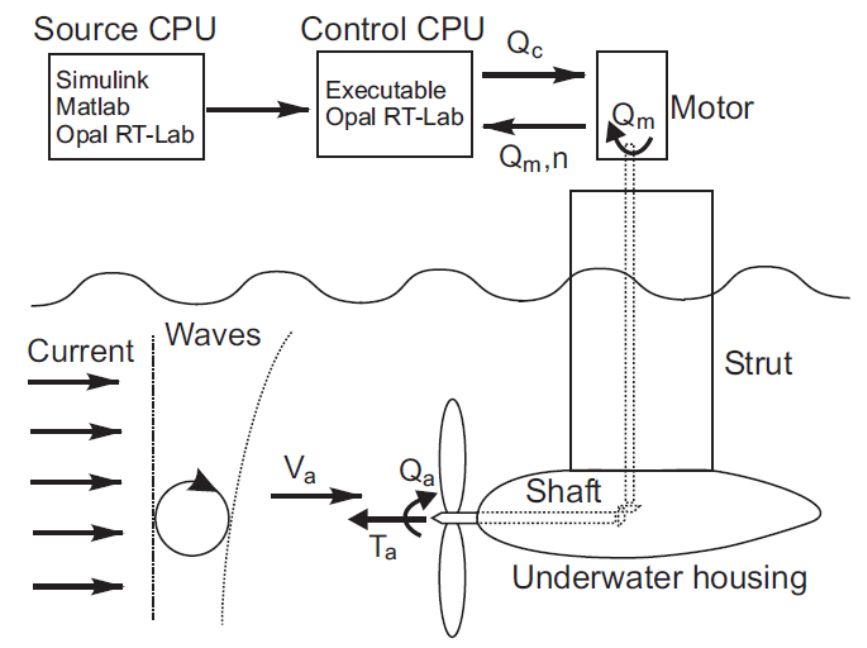

Figure 2 - Sketch of the experimental setup

The shaft friction turned out to affect the performance of the torque and power controllers. Over the course of the experiments, the friction compensation coefficients were found to be in the range $Q_{f 0} \in[0.8,1.0]$ and $Q_{f 1} \in[0.009,0.011]$.

The friction compensation was chosen with $Q_{f 0}=1.0 \mathrm{Nm}$ and $Q_{f l}=0.01 \mathrm{Nm}$. The inertia compensation was not needed for the small model-scale propeller. The control coefficients were chosen as $K_{T C}=K_{T O}=0.513$ and $K_{Q C}=K_{Q O}=0.0444$. For the combined controller (266) the weighting function parameters were chosen as $[\mathrm{r}, \mathrm{p}, \mathrm{k}]=[4,0.5,1]$. This gave a pure torque controller for $n<0.5 \mathrm{rps}$ and a pure power controller for $n>3 \mathrm{rps}$. The shaft speed PI controller parameters were chosen as $K_{p}=0.2$ and $T_{i}=0.05 s$.

In the load torque observer, the gains were chosen as $k_{a}=15$ and $\mathrm{k}_{b}=-25$. In the ventilation detection scheme, the parameters were chosen as $\beta_{v, \text { on }}=0.6$ and $\beta_{v, \text { off }}=0.9$, and the detection delay was set to $T_{\text {vent }}=1 \mathrm{~s}$. For the proposed anti-spin controller, the settings for the primary anti-spin action were $\gamma_{\text {rise }}=1 \mathrm{~s}^{-1}, \gamma_{\text {fall }}=-1 \mathrm{~s}^{-1}$, and unless otherwise stated $\tau_{\gamma}=0.3 \mathrm{~s}$. For the secondary antispin action, the filter time constant was chosen as $\tau_{\mathrm{n}}=0.05 \mathrm{~s}$, and the rate limits were chosen as $n_{\text {rise }}=3 \mathrm{~s}^{-2}$ and $n_{\text {fall }}=-3 \mathrm{~s}^{-2}$. The desired shaft speed during ventilation was set to $n_{a s}=9 \mathrm{rps}$. The 
latter choice was motivated by observations during the tests, where it seemed that the most violent dynamic loading disappeared below 10rps. A maximum shaft speed of $n_{\max }=25 \mathrm{rps}$ was enforced.

The anti-spin control scheme appears to be robust to parameter tuning. In order to avoid detection chattering, however, it is important not to choose $\beta_{v, \text { on }}$ too large. In addition, if the rate limits are chosen too low or the filter time constants too large, the anti-spin controller response will become slow, and the shaft speed will be allowed to increase more during ventilation.

A total of 36 tests were run with zero advance velocity and varying motor setpoints. Each setpoint was run for approximately 60 seconds in order to get good statistical values. The nominal thrust and torque coefficients $K_{T O}$ and $K_{Q O}$ for varying propeller shaft speed $n$ and $V_{a}=0$ are shown in Fig.4, where also the mean values used in the rest of the work are shown. The resulting mean values were $K_{T O}=0.5359$ and $K_{Q 0}=0.0832$. The shaft friction for the tested propeller was found as the steady-state difference between the motor torque $Q_{m}$ and the propeller torque $Q_{a}$, and is plotted versus $n$ fig. 3 .

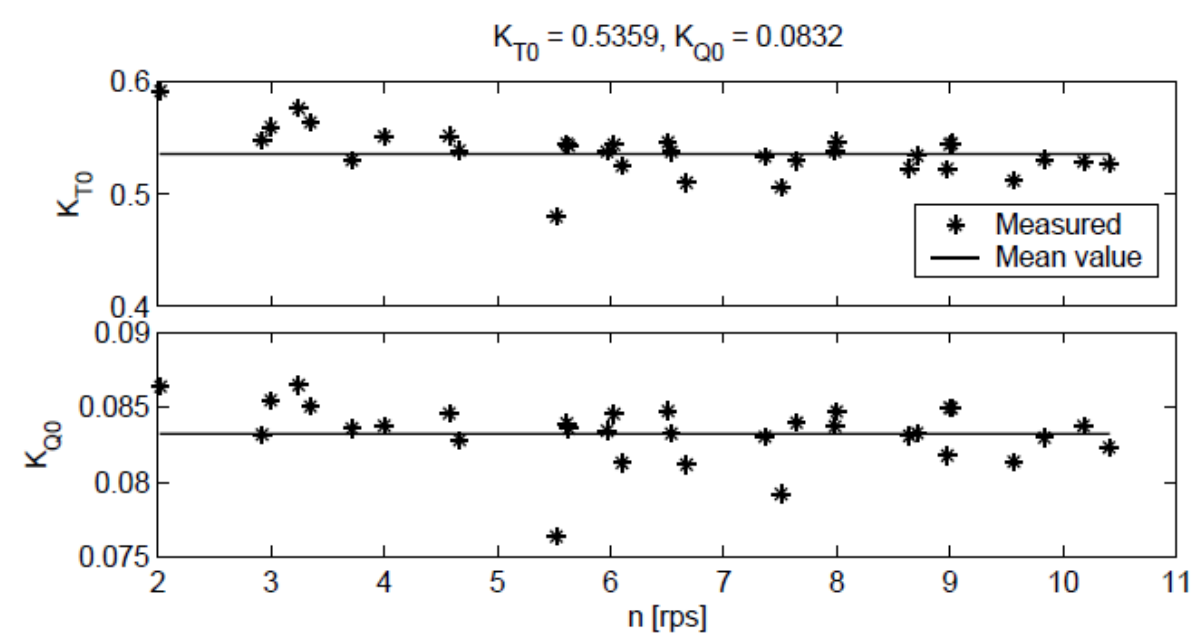

Figure 3 - Nominal thrust coefficient $K_{T O}$ and nominal torque coefficient $K_{Q 0}$ measurements for varying shaft speed $n$

In the sensitivity tests the thrust reference was kept constant at $T_{r e f}=100 \mathrm{~N}$, the advance velocities were $V_{a}=\{-1,-0.5,0,0.5,1,1.5\} \mathrm{m} / \mathrm{s}$. and the speed, torque and power controllers were used. Each combination was run 3 times, giving a total of 54 runs. The performance of the three controllers are summed up in Fig.4, where the propeller thrust $T_{a}$, propeller torque $Q_{a}$, shaft speed $n$, motor torque $Q_{m}$ and motor power $P_{m}$ are shown for varying advance speeds. The friction compensation is not included in the plots of motor torque and power. It is clear that the three controllers obtain their objectives: the shaft speed controller keeps the shaft speed constant, the torque controller keeps the motor torque constant, and the power controller keeps the motor power constant. As the advance speed increases, the effective angle of attack of the propeller blades is decreased, and the propeller loading decreases for a constant shaft speed. This can be seen in terms of reduced propeller thrust and torque at increasing advance velocities for the shaft speed controller: at $V_{a}=1.5 \mathrm{~m} / \mathrm{s}$ the propeller thrust is reduced from $100 \mathrm{~N}$ to $18 \mathrm{~N}$. The torque and power controllers have much better performance, since they will increase the shaft speed as the propeller loading decreases: $V_{a}=1.5 \mathrm{~m} / \mathrm{s}$ the propeller thrust is reduced from $100 \mathrm{~N}$ to $65 \mathrm{~N}$ and $50 \mathrm{~N}$ respectively. The reason for the propeller torque not remaining constant for increasing advance velocities are inaccuracies in the friction model.

The sensitivity to variations in advance velocity $V_{a}$ can be studied by representing $K_{T}$ and $K_{Q}$ as functions of $V_{a}$ and ignoring all other loss effects. The experimentally determined sensitivity functions for varying advance velocity are shown in Fig.7 This confirms that the shaft speed controller is the most sensitive and the torque controller the least sensitive to variations in advance velocity. 
To validate the dynamic performance of the controllers when subject to rapidly changing inflow to the propeller a total of 34 tests in regular and irregular waves were performed. The thrust reference was $T_{d}=100 \mathrm{~N}$ and the carriage was kept stationary. A comparison of the controller performance in regular waves with wave height $8 \mathrm{~cm}$ and period $1 \mathrm{~s}$ is shown in fig. 4 . DP functionality has been simulated, such that all controllers gave the same mean thrust. The results are summarized in the following:

- the shaft speed controller keeps the shaft speed constant, and has to vary the motor torque and power in order to achieve this. The resulting propeller thrust and torque have the largest variance;

- the torque controller keeps the motor torque constant, and as a result the shaft speed varies with the loading. The resulting propeller thrust and torque have the smallest variance;

- the power controller keeps the motor power constant, and as a result both the shaft speed and motor torque varies with the loading. The resulting propeller thrust and torque lie between the shaft speed and torque controller values.

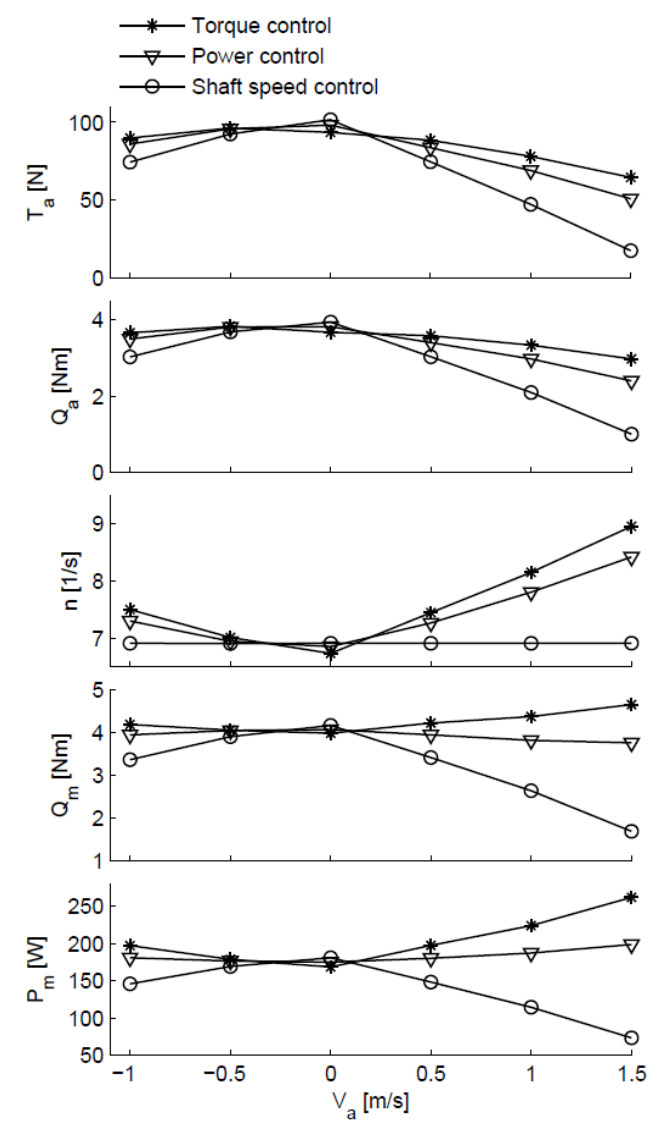

Figure 4 - Comparison of propeller thrust $T_{a}$, propeller torque $Q_{a}$, shaft speed $n$, motor torque $Q_{m}$ and motor power $P_{m}$ for the shaft speed, torque and power controllers in varying advance velocities $V_{a}$

The anti-spin control scheme was tested in a variety of operating conditions: for constant and time-varying thrust references, in waves, with a calm free surface and forced vertical motion of varying amplitude $A_{v}$, period $T_{v}$, and mean submergence $h_{0}$, and in combinations of waves and vertical motion. In the results presented here, the thrust reference was kept constant during forced vertical motion with a calm free surface. This improved repeatability and enabled comparison of the various controllers, since the time series could be synchronized by comparing the relative vertical motion of the propeller. Because of the chaotic nature of ventilation, the actual operational conditions for the propeller vary from one test run to another. However, the repeatability is in general good. The results presented below are for $h_{0}=15 \mathrm{~cm}, A_{v}=15 \mathrm{~cm}$, and $T_{v}=5 \mathrm{~s}$.

Fig. 5 shows comparisons of the thrust $T_{a}$, propeller torque $Q_{a}$, shaft speed $n$, motor torque $Q_{m}$ and motor power $P_{m}$ for four different thruster controllers during a ventilation incident with $T_{r}$ $=200 \mathrm{~N}$. The ventilation incident starts at $t \approx 11.2 \mathrm{~s}$, and terminates at $t \approx 14.5 \mathrm{~s}$. The compared 
controllers are shaft speed PI control, torque control, power control, and the proposed anti-spin controller based on combined torque/power control. With anti-spin activated, both the primary (8) and the secondary (10) anti-spin actions were used. The time series show that the torque controller and the power controller both lead to propeller racing. The shaft speed controller and the anti-spin controller limit the shaft speed as intended, with the secondary anti-spin action giving a slightly reduced shaft speed during ventilation. The resulting thrust during ventilation is about the same for all controllers. That is, the anti-spin controller, which reduces the shaft speed to 9rps during ventilation, produces the same thrust as the torque controller, which races to the imposed limit of 25rps. The power consumption of the torque controller is unacceptably high, whereas the power controller keeps the power consumption limited. The shaft speed and anti-spin controllers give a lower power consumption during ventilation, but this is not considered to be a problem.

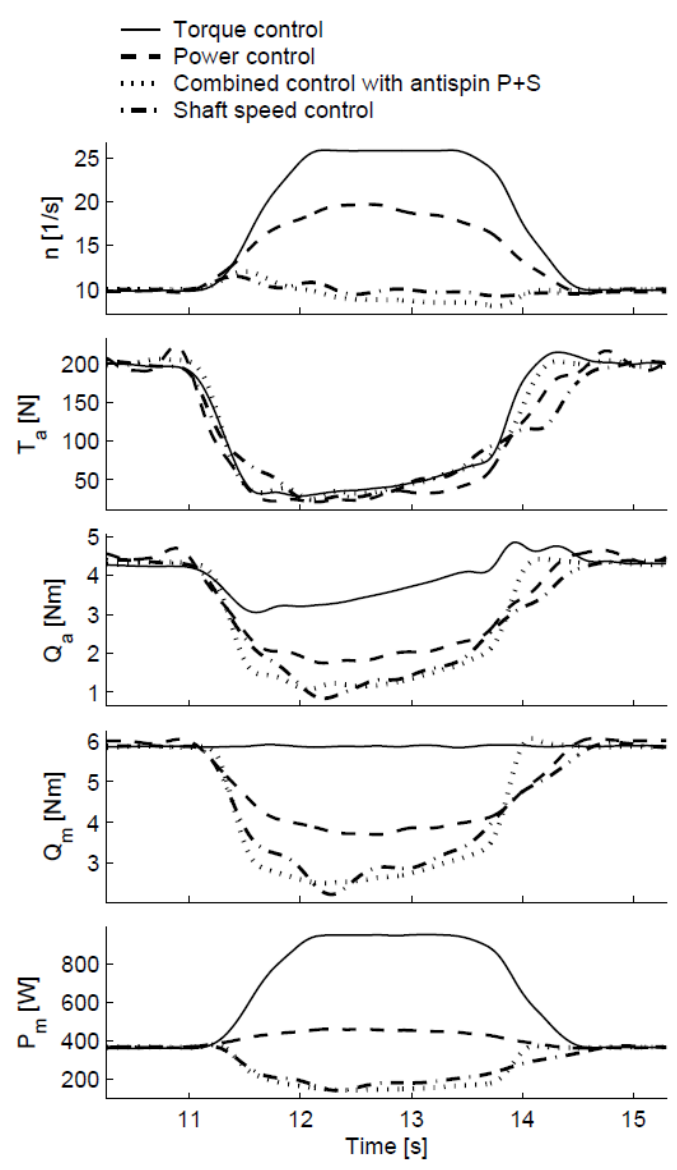

Figure 5 - Comparison of four controllers during a ventilation incident at $T_{r}=200 \mathrm{~N}$

Fig.6 shows details from the anti-spin controller during a ventilation incident: propeller torque $Q_{a}$ versus estimated propeller torque $\hat{Q}_{a}$, estimated torque loss factor $\hat{\beta}_{Q}$ and ventilation detection signal $\zeta$, torque modification factor $\gamma$, deviation of $\gamma$ from the measured $\beta_{Q}$, and the desired shaft speed $n_{\text {ras }}$. The time series show that the anti-spin controller, including torque observer and ventilation detection, performs as intended. 

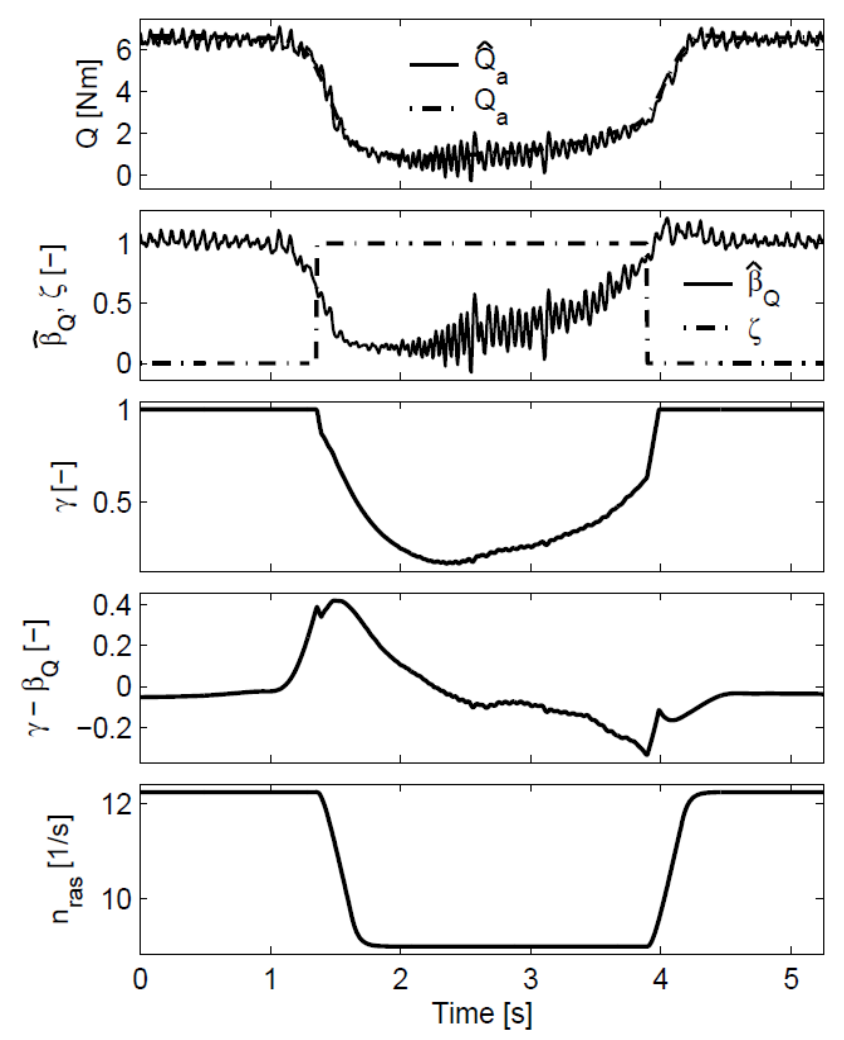

Figure 6 - Time series of the main parameters in the anti-spin control law with primary and secondary control actions during a ventilation incident at $T_{r}=300 \mathrm{~N}$

Conclusions. Low-level controllers based on shaft speed, torque, and power control for electrically driven thrusters on vessels in normal operating conditions have been investigated, and evaluated according to three main performance criteria. The conventional shaft speed controller gave the thrust, torque, and power with the largest variance, and it was the least robust to disturbances in the in-line flow velocity. The torque controller produced the thrust and torque with the smallest variance, and was superior with respect to compensating for thrust losses due to disturbances in the inflow. The power controller gave the least oscillations in the power, with the resulting propeller thrust and torque in-between the shaft speed and torque controller values. The combined torque and power controller gave the overall best improvement in the performance from low to high loadings. Steady-state sensitivity functions describing the performance of the various controllers in terms of resulting thrust, shaft speed, torque, and power when subject to thrust losses were presented. Experiments illustrated the difference in performance and robustness of the different controllers.

It has been shown that torque and power control is a feasible solution for high-performance thruster control only if special precautions are taken during extreme environmental conditions, when the propeller may be subject to ventilation and in-and-out-of water effects. To solve this problem, an anti-spin thruster controller has been designed. The thruster performance was monitored by a load torque observer, and the anti-spin controller was triggered by a ventilation detection scheme. The anti-spin controller took control of and lowered the shaft speed. Experiments with a model scale propeller were presented. The results showed that the torque and power controllers with anti-spin had comparable performance to that of a well-tuned shaft speed PI controller during ventilation, without compromising the superior performance of torque and power control in normal conditions. 


\section{СПИСОК ВИКОРИСТАНОЇ ЛІТЕРАТУРИ}

1. Smogeli, O. N. Control of Marine Propellers - From Normal to Extreme Conditions. PhD Thesis 2006:187, Department of Marine Technology. Faculty of Engineering Science \& Technology, NTNU, Norway, 2006.

2. Smogeli, O. N. and A. J. Sørensen. Antispin Thruster Control for Ships. IEEE Transaction on Control System Technology. 2009. Vol. 17, No. 6. P. 1362-1375.

3. Hespanha J. P. Tutorial on Supervisory Control, Lecture Notes for the Workshop Control using Logic and Switching for the Conference on Decision and Control, Orlando, Florida, US, 2001.

4. Haskara, 'I., Ü. Özgüner, J. Winkelman. Wheel slip control for antispin acceleration via dynamic spark advance. Control Engineering Practice. 2000. 8.

5. Johansen, T. A., J. Kalkkuhl and I. Petersen. Hybrid Control Strategies in ABS. In. Proc. of American Control Conference (ACC'01). Arlington, VA, USA, 2001.

6. Doschenko G. G. Microcontroller ship system of energy saving Energy Saving System. Adaptation of Science, Education and Business to World Innovative Megatrends : International collective monograph. Science and Innovation Center, Ltd. St. Louis. Missouri, Thessaloniki. 2018. P. 129-134. DOI:10.6084/m9.figshare.7814393.v1

7. Nahovskyi D. A. Construction features and necessity of pre-testing DP-systems. Adaptation of Science, Education and Business to World Innovative Megatrends : International collective monograph. Science and Innovation Center, Ltd. St. Louis. Missouri, Thessaloniki. 2018. P. 124-129. DOI:10.6084/m9.figshare.7814393.v1

8. Stephens, R. I., K. J. Burnham and P. J. Reeve. A practical Approach to the Design of Fuzzyy Controllers with Application to Dynamic Ship Positioning. In Proc. of IFAC Conference on Control Applications in Marine Systems, Trondheim, Norway, 1995.

9. Tannuri, E. A., A.C. Agostinho, H.M. Morishita, L. and Moratelli Jr. Dynamic Positioning Systems: An Experimental Analysis of Sliding Mode Control. Control Engineering Practice, CEP 18-10, 2010. P. 1121-1132.

10. Sorensen, A. J. and O. N. Smogeli. Torque and Power Control of Electrically Driven Marine Propellers. Control Engineering Practice, CEP 17-9, 2009. P. 1053-1064.

11. Perez, T. and A. Donaire. Constrained Control Design for Dynamic Positioning of Marine Vehicles with Control Allocation Modelling Identification and Control, MIC 30- 2, 2009. P. 57-70.

12. Черных И. В. SimPowerSystems: Моделирование электротехнических устройств и систем в Simulink : веб-сайт. URL : https://docs.exponenta.ru/physmod/sps/index.html.

13. Тимченко В. Л., Ухин О. А. Робастно-оптимальная стабилизация морских подвижных объектов в режиме динамического позиционирования. Электротехнические $u$ компьютерные системы. К. : Техника. 2014. № 13 (89). С. 19-26.

14. Григорьев А. В., Васин И. М., Хомяк В. А. Комлпексный подход при создании судновых энергетических систем и установок. Судостроение. 2008. № 2. С.30-31.

15. Григорьев А. В., Глеклер Е. А. Перспективная судовая единая электроэнергетическая установка. Эксплуатация морского транспорта : ежекварт. сб. науч. cm. СПб. : Феникс, 2008. Вып. № 3 (53). С.68-70.

\section{REFERENCES}

1. Smogeli, O. N. (2006). Control of Marine Propellers - From Normal to Extreme Conditions. Candidate's thesis. NTNU, Norway : Department of Marine Technology, Faculty of Engineering Science \& Technology.

2. Smogeli, O. N. \& A. J. Sørensen. (2009). Antispin Thruster Control for Ships. IEEE Transaction on Control System Technology, Vol. 17, No. 6, 1362-1375. 
3. Hespanha, J. P. (2001). Tutorial on Supervisory Control. Lecture Notes for the Workshop Control using Logic and Switching for the Conference on Decision and Control, Orlando, Florida, US.

4. Haskara, 'I., Özgüner, Ü. \& Winkelman, J. (2000). Wheel slip control for antispin acceleration via dynamic spark advance. Control Engineering Practice, 8.

5. Johansen, T. A., Kalkkuhl, J. \& Petersen, I. (2001). Hybrid Control Strategies in ABS. In. Proc. of American Control Conference (ACC'01). Arlington, VA, USA.

6. Doschenko G.G. (2018). Microcontroller ship system of energy saving Energy Saving. Adaptation of Science, Education and Business to World Innovative Megatrends : International collective monograph. Science and Innovation Center, Ltd. St. Louis. Missouri, Thessaloniki. 129-134. DOI:10.6084/m9.figshare.7814393.v1.

7. Nahovskyi D. A. (2018). Construction features and necessity of pre-testing DPsystems. Adaptation of Science, Education and Business to World Innovative Megatrends : International collective monograph. Science and Innovation Center, Ltd. St. Louis. Missouri, Thessaloniki. 124-129. DOI:10.6084/m9.figshare.7814393.v1.

8. Stephens, R. I., Burnham, K. J. \& Reeve, P. J. (1995). A practical Approach to the Design of Fuzzyy Controllers with Application to Dynamic Ship Positioning. In Proc. of IFAC Conference on Control Applications in Marine Systems, Trondheim, Norway.

9. Tannuri, E. A., Agostinho, A. C., Morishita H. M. \& and Moratelli Jr. (2010). Dynamic Positioning Systems: An Experimental Analysis of Sliding Mode Control. Control Engineering Practice, CEP 18-10, 1121-1132.

10. Sorensen, A. J. \& Smogeli O. N. (2009). Torque and Power Control of Electrically Driven Marine Propellers. Control Engineering Practice, CEP 17-9, 1053-1064.

11. Perez, T. \& Donaire, A. (2009). Constrained Control Design for Dynamic Positioning of Marine Vehicles with Control Allocation Modelling Identification and Control, MIC 30-2, 57-70.

12. Chernihkh I. V. SimPowerSystems: Modelirovanie ehlektrotekhnicheskikh ustroyjstv i sistem v Simulink. Retrieved from: https://docs.exponenta.ru/physmod/sps/index.html.

13. Timchenko, V. L. \& Ukhin O. A. (2014). Robastno-optimaljnaya stabilizaciya morskikh podvizhnihkh objhektov $\mathrm{v}$ rezhime dinamicheskogo pozicionirovaniya. Ehlektrotekhnicheskie i kompjyuternihe sistemih, 13 (89). Kyev : Tekhnika. 19-26.

14. Grigorjev, A.V., Vasin I. M. \& Khomyak V. A. (2008). Komlpeksnihyj podkhod pri sozdanii sudnovihkh ehnergeticheskikh sistem i ustanovok. Sudostroenie, 2, 30-31.

15. Grigorjev, A. V. \& Glekler E. A. (2008). Perspektivnaya sudovaya edinaya ehlektroehnergeticheskaya ustanovka. Ehkspluataciya morskogo transporta: ezhekvart. sb. nauch. st., 3 (53). Sanct-Peterburg : Feniks. 68-70.

Наговский Д. А., Дощенко Г. ДВИЖЕТЕЛЯМИ СУДНА В ИЗМЕНЯЮЩИХСЯ УСЛОВИЯХ ЭКСПЛУАТАЦИИ

Обосновано, что для повышения эксплуатационных характеристик движетелей судна необходимо использовать управление по моменту и мощности. Показано, что управление по крутящему моменту и мощности является возможным решением для высокоэффективного управления двигателем только в том случае, если предпринимаются особые меры предосторожности в экстремальных условиях окружающей среды, когда винт может подвергаться воздействию турбулентности и выхода из воды. Разработан контроллер свободного вращения винта.

Показаны результаты того, что регуляторы по крутящему моменту и мощности с контроллером свободного вращения имеют производительность, сопоставимую с хорошо настроенным PIрегулятором скорости вала во время эффекта вентиляции, без ущерба для характеристик управления крутящим моментом и мощностью в нормальных условиях.

Ключевые слова: контроллер свободного вращения винта, управление, движитель судна, крутящий момент, модель, мощность, эффект вентиляции. 
Наговський Д. А., Дощенко Г. Г. МЕТОДИ УПРАВЛІННЯ ПРОПУЛЬСИВНИМИ РУШІЯМИ СУДНА В ЗМІННИХ УМОВАХ ЕКСПЛУАТАЦІЇ

Обтрунтовано, що для підвищення експлуатаційних характеристик рушія судна необхідно використовувати закон управління, який використовує показники моменту та потужності на гвинті рушія. Показано, що управління, в якому критерісм оптимізації є крутний момент і потужність на гвинті рушія судна, є можливим рішенням для високоефективного управління двигуном тільки в тому випадку, якщо застосовуються особливі запобіжні заходи в екстремальних умовах навколишнього середовища, коли гвинт пропульсивного рушія може піддаватися впливу турбулентності та виходити із води. Розроблено контролер вільного обертання гвинта. Контролер використовує в свойи роботі показники динаміки гвинта пропульсивного рушія, приводного електродвигуна, розрахункові показники компенсаиії інериї̈ гвинта. Поведінка системи при зміні куту нахилу лез гвинта не досліджувалась $i$ буде внесена в закон управління в подальшій роботі. При проведенні досліджень використовувався кут нахилу лез гвинта в розмірі 70\%. В результаті використання такого контролера гвинт пропульсивного рушія судна обмежується в швидкості обертання при ефекті вентиляції, тобто за умови виходу гвинта з води. Для перевірки виконаних досліджень та розрахунків поставлено 34 досліди на фізичній моделі об'єкта управління. Досліди враховували окрему та групову фіксацію параметрів потужності, швидкості обертання та моменту гвинта пропульсивного рушія фізичної моделі.

Показані отримані результати того, що регулятори, які використовують в своєму законі управління критерій оптимізації по крутному моменту та потужності на гвинті пропульсивного рушія з контролером вільного обертання мають продуктивність, яку можна порівняти з добре налагодженим РІ-регулятором швидкості обертання валу під час ефекту вентиляиії, без шкоди для характеристик управління крутним моментом і потужністю гвинта пропульсивного рушія 6 нормальних умовах. Це дозволяє замінити стандартні методи управління пропульсивними рушіями, які не враховують ефекту вільного обертання валу рушія без навантаження, тим самим створюючи проблеми при управлінні судном та в експлуатації електрообладнання пропульсивного рушія судна.

Ключові слова: контролер вільного обертання гвинта, управління, рушій судна, крутний момент, швидкість обертання, модель, потужність, ефект вентиляиії.

(C) Наговський Д. А., Дощенко Г. Г.

Статтю прийнято

до редакції 25.04.19

108До рубрики включено статті за тематичною спрямованістю

«Автомаизація та комп 'ютерно-інтегровані технології» 